\title{
CENTRAL NEUROCYTOMA
}

\section{Report of two cases}

\author{
Guilherme Borges', Hoyama Costa Pereira², Edmur Franco Carelli', \\ Yvens Barbosa Fernandes', Leonardo Bonilha ${ }^{3}$, Maria Fernanda Roma4, \\ Verônica A. Zanardi ${ }^{5}$, José R. Menezes Netto ${ }^{5}$, André A. Schenka ${ }^{6}$, Luciano S. Queiroz ${ }^{7}$
}

\begin{abstract}
Introduction: Central neurocytomas are rare neuroectodermal tumors believed to arise from the subependymal matrix of the lateral ventricles. Case reports: A 26-year-old woman and a 33-year-old man each had a large, heterogeneous, contrast enhancing mass in the lateral ventricles at the foramen of Monro causing bilateral hydrocephalus. The woman died after surg e ry, but the man is asymptomatic after three years. Histopathology: Both tumors were composed of isomorphic rounded cells positive for synaptophysin, chromogranin and NSE, while some reacted for GFAP, vimentin and S-100 protein. Electron microscopy revealed neuropil-like tissue between cells, but synapses were rare.
\end{abstract}

KEY WORDS: central neurocytoma, brain tumors, immunohistochemistry, synaptophysin, electron microscopy.

\begin{abstract}
Neurocitoma central: relato de dois casos
RESUMO - Introdução: Ne u rocitoma central é um tumor neuroectodémico raro, geralmente localizado nos ventrículos laterais. Relato de casos: Uma mulher de 26 anos e um homem de 33 anos apresentaramse com hipertensão intracraniana. Exames de imagem revelaram tumor intraventricular heterogêneo, que im pregnava por contraste, ocupando os ventrículos laterais e causando hidrocefalia. A mulher faleceu no pós-operatório e o homem está livre de recidiva após três anos. Histopatologia: Ambos os tumores eram sólidos, com células arredondadas, lembrando oligodendroglia, positivas para sinaptofisina, cromogranina e NSE e algumas para GFAP, vimentina e proteína S-100. Microscopia eletrônica mostrou neurópilo entre os corpos celulares, mas sinapses eram raras.
\end{abstract}

PALAVRAS-CHAVE: neurocitoma central, tumores cerebrais, imuno-histoquímica, sinaptofisina, microscopia eletrônica.

Central neurocytoma is an uncommon neuroecto de rmal tumor of young adults, usually situated in the lateral ventricles at the foramen of Monro, and was first individualized by Hassoun et al. ${ }^{1}$. Histologically it often strikingly resembles oligodendroglioma. The diagnosis must be based on immunohistochemistry for neuronal antigens such as synaptophysin and neuron-specific enolase (NSE) ${ }^{2}$ or on electron microscopy demonstrating synapselike structures ${ }^{3,4}$. Central neurocytomas are relatively well delimited and have good prognosis ${ }^{5,6}$.

\section{CASES}

Case 1 - A 26-year-old woman presented with a progressive 6-month history of headache. Two and half months earlier she noticed decrease in muscle strength and tingling in both lower limbs, loss of visual acuity and urinaryincontinence. On examination, she was alert and cooperative. There was mild anisocoria, mild tetraparesis, spasticity and hyperreflexia, more marked on the left, bilateral ankle clonus, left sided dysmetria and a diff iculty for fine movements with the left hand. Sensibility was normal. Magnetic resonance imaging (MRI) (Fig 1) demonstrated a large tumor $(8 \times 6 \times 5 \mathrm{~cm})$ straddling both lateral ventricles at the foramina of Monro, associated with supratentorial hydrocephalus. The lesion was heterogeneous, with solid and cystic areas. The solid component was predominantly isointense in $\mathrm{T} 1$ and $\mathrm{T} 2$ weighted images and was strongly enhanced by contrast. Cystic areas were iso- or hypointense in T1 and iso- or hyperintense in T2. Large vessels were noted with-

\footnotetext{
State University of Campinas, School of Medicine (FCM-UNICAMP), Campinas SP, Brazil, Discipline of Neurosurgery. ${ }^{1}$ Professor; ${ }^{2}$ Resident; ${ }^{3}$ Postgraduate student; ${ }^{4}$ Graduate student; Department of Radiology; ${ }^{5}$ Professor, Department of Pathology; ${ }^{6}$ Postgraduate student; ${ }^{7}$ Professor.

Received 1 March 2005, received in final form 19 May 2005. Accepted 6 July 2005.

Dr. Luciano S. Queiroz - Departamento of Pathology / FCM-UNICAMP / Caixa Postal 6111 - 13083-970 Campinas SP - Brazil. E-mail: gradanat@fcm.unicamp.br.
} 


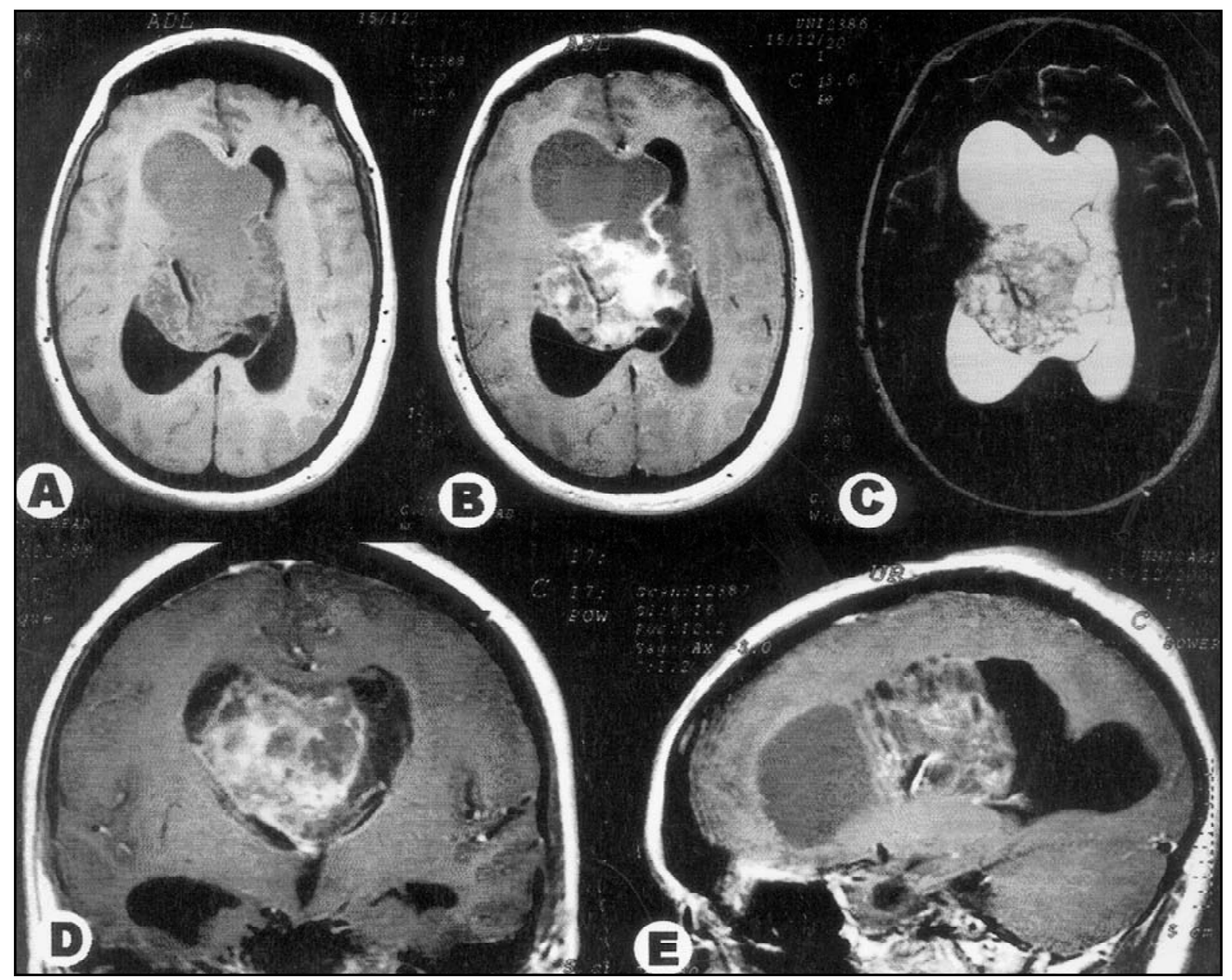

Fig 1. Case 1. Large heterogeneous tumor occupying the body, trigone and anterior horn of the right lateral ventricle, caus ing shift of the septum pellucidum and extending into the left ventricle. The lesion contains cystic and solid areas, the latter with strong contrast enhancement, and thick intratumoral vessels (flow-void). There is marked secondary hydrocephalus . A) $T 1, B, D, E) T 1$ after intravenous contrast; C) $T 2$ weighted images.

in the lesion. An intratumoral cyst occupied the anterior horn of the right lateral ventricle, causing marked midline shift. At surgery the tumor proved extremely vascularized. A stormy postoperative course with brain swelling and intraventricular hemorrhage led to death on the third day.

Case 2 - A 33-year-old man had a one-year history of throbbing headache in the right temporal region which irradiated to other cranial regions. Short lived episodes of dizziness, loss of vision, tingling in the right side of the face and diplopia starting 40 days earlier we re also reported. General physical and neurological examinations were normal. CT and MRI scans demonstrated a mass measuring $6 \times 4 \times 4 \mathrm{~cm}$ in the right lateral ventricle, based in the foramen of Monro, which filled up the body and trigone and extended into the left ventricle. The lesion caused midline shift and bilateral hy d rocephalus. It appeared well delimited and heterogeneous, with solid and small cystic areas throughout.
Contrast enhancement was mild and limited to the solid areas. A right frontal craniotomy was performed and the tumor was removed through a transcortical transventricular approach. He was discharged two weeks later with slight left-sided hemiparesis. He is currently well th reeyears after surg e ry. A recent control MRI showed an uncharacteristic cyst at the tumor site but no recurrence.

Histopathological examination - Both tumors resembled each other closely. In HE-stained sections, the lesions were composed of markedly regular cells arranged in sheets, with rounded nuclei and scanty eosinophilic cytoplasm. The latter was often clear or showed a perinuclear vacuole, imparting a 'fried egg' appearance resembling oligodendroglia (Fig 2A, B). The tumors were well demarcated from the surrounding tissue. There were no perivascular pseudorosettes, Homer Wright rosettes or ganglionic differentiation. Rare mitotic figures were found in case 2 but not in case 1 . Necrosis and endothe- 


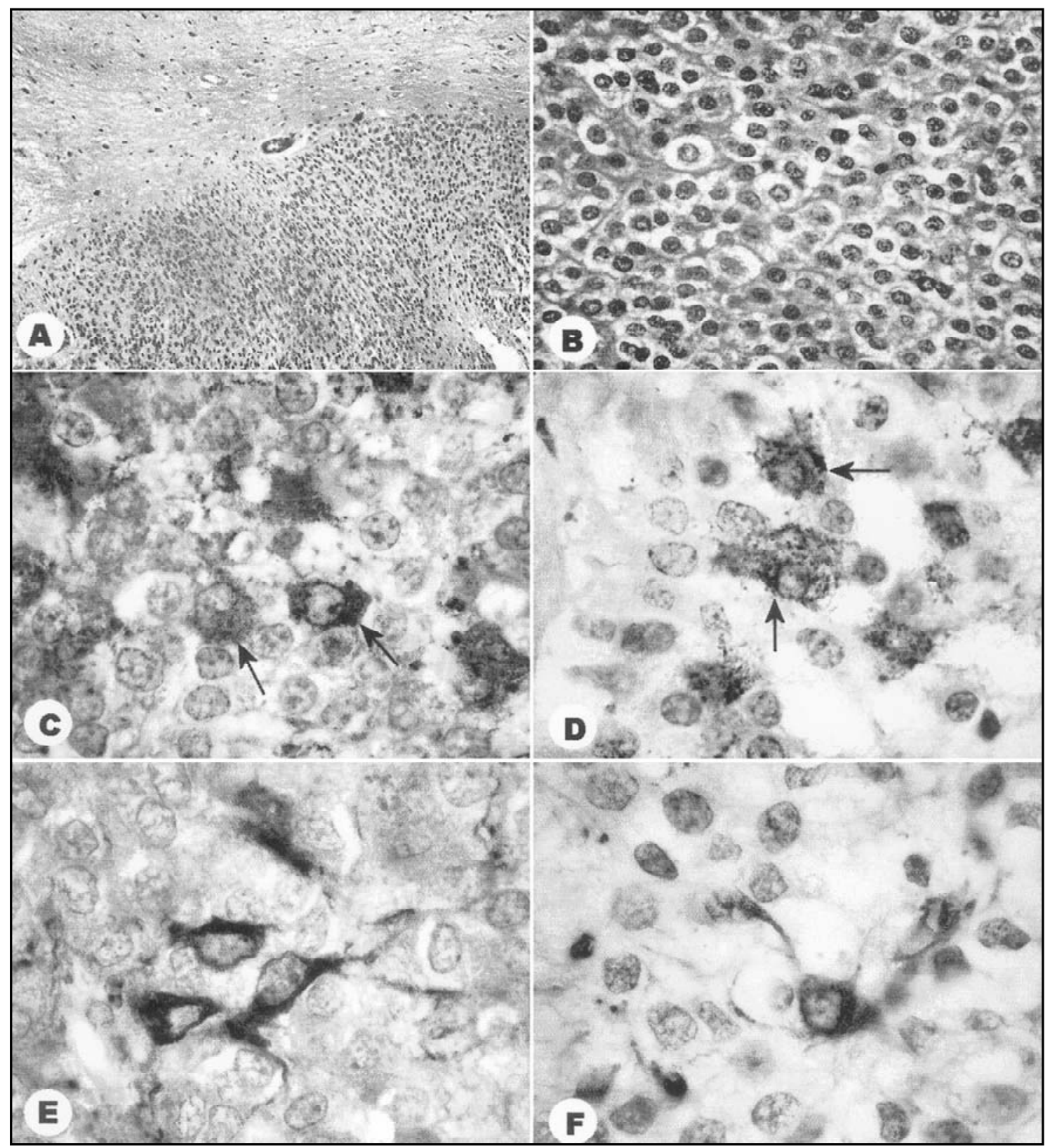

Fig 2. Case 1. A) Tumor is composed of isomorphic cells well demarcated from the surrounding brain. HE. $x$ 40. B) Neoplastic cells with rounded regular nuclei and scanty cytoplasm with perinuclear halo, mimicking oligodendro glioma. HE, x 200. Immunohistochemical reactions for synaptophysin (C) and chromogranin (D) show cells with cyto plasmic positivity (arrows). $x$ 400. Immunohistochemical reactions for GFAP (E) and vimentin (F) demonstrate perinu clear cytoplasm and processes in tumor cells with astrocytic differentiation. $x 400$.

lial proliferation were not observed. Some calcification was seen in case 2 .

\section{Immunohistochemistry}

Neuronal antigens - In both cases the cytoplasm of tumor cells stained variably for synaptophysin, chromogranin and neuron-specific enolase (Fig $2 C, D$ ). Reaction was often strong in one cell or group of cells and weak or negative in neighboring cells. The intensity of reaction and number of positive cells were greater in case 1 . No reaction was observed with neurofilament protein antibody.

Astroytic antigens - In both cases, a number of cells reacted positively for glial fibrillary acidic protein (GFAP), vimentin and $\mathrm{S}-100$ protein (Fig $2 \mathrm{E}, \mathrm{F}$ ). Positive cells were small, with scanty cytoplasm and few simple processes. The appearance was not reminiscent of preexisting reactive astrocytes that might have been trapped within the tumor.

$\mathrm{Ki}-67$ was positive in less than $1 \%$ of nuclei in case 1 


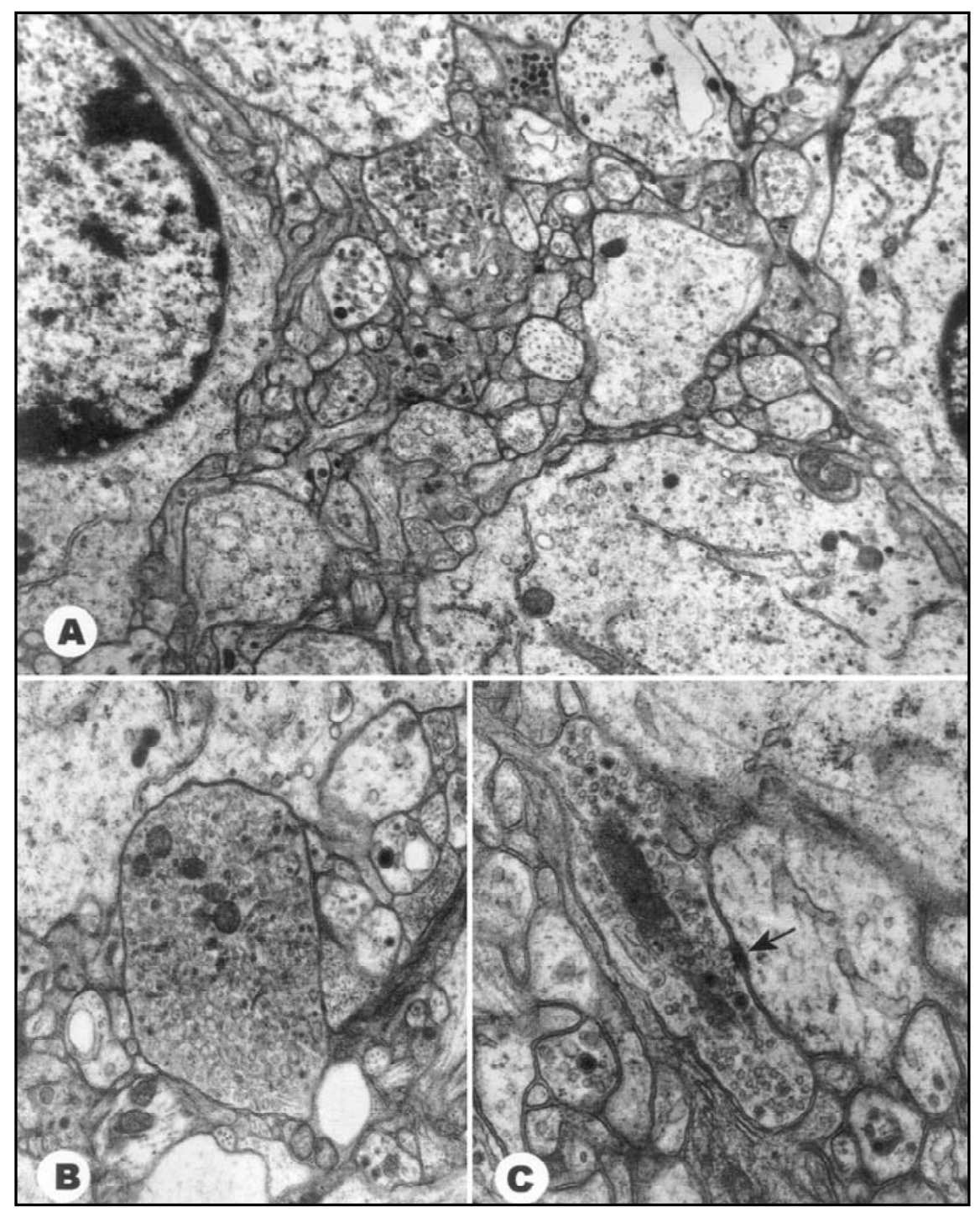

Fig 3. Case 1. Electron microscopy. A) The tissue between tumor cell bodies (left and right, with nuclei) is composed of abundant, closely apposed membrane limited profiles simi lar to normal neuropil. $x$ 4000. B) Many profiles are filled with structures with resemblance to synaptic vesicles, and also contain mitochondria. $x$ 10000. C) A rare example of synapse: the axonal terminal at center left contains clear synaptic vesicles and a few dense core vesicles. The dendritic terminal at center right is electron lucent and contains microtubules and profiles of smooth endoplasmic reticulum. An electron-dense membrane patch sug gestive of synaptic density is arrowed. $x 20000$.

and 3 to $5 \%$ in case 2 (no counting was attempted). There was no reaction for $\mathrm{p} 53$.

Electron microscopy - In both cases, tumor cells had rounded nuclei with dispersed chromatin and small nucleoli, smooth and rough endoplasmic reticulum and mitochondria. Between cell bodies, a meshwork of intertwined cell processes closely resembling normal neuropil was observed (Fig 3A). In case 1, several profiles contained small vesicles with a clear center, similar to synaptic vesicles, and fewer dense core vesicles (Fig 3B). In other processes, microtubules and/or intermediate fila- ments were noted. Occasionally, there were synapse-like structures (Fig 3C). In case 2 vesicles or synapses could not be demonstrated.

\section{DISCUSSION}

Our cases fit into the clinical, radiological and pathological features of central neurocytoma reported in the literature. In both, the tumor was situated in the lateral ventricles, in the region of the foramen of Monro and had reached large size, causing intracranial hypertension and secondary 
hydrocephalus. The lesions were heterogeneous, solid and cystic, and appeared well delimited. Contrast enhancement was strong in case 1 and mild in case 2 . In Robbins et al. series ${ }^{5}$, contrast enhancement was found in three of seven tumors. It was variable in the five patients of Zhang et al. ${ }^{7}$. The radiologic appearance of neurocytomas and other intraventricular tumors has been reviewed ${ }^{8,9}$.

Pathologically, the similarity to oligodendroglioma in HE stained sections was striking. Calcification, seen in case 2 only, was found in about half of cases of the series of von Deimling et al. ${ }^{2}$. Well fo rmed Homer Wright rosettes were not found ${ }^{2,5}$.

Immunohistochemistryfor synaptophysin and chromogranin was positive in many cells, more st rongly in case 1, supporting origin in or differe ntiation into neuronal elements. This was confirmed by electron microscopy, which showed synaptic structu res in case 1. Case 2 appeared less differentiated, as immunohistochemical reaction for neuronal antigens was weaker and true synapses were not found. The nuclei marked by Ki- 67 were also more nu$m$ e rous in case 2 . This patient remains tumor free th ree years after treatment, while case 1 succumbed to early postoperative complications.

Synaptophysin is considered the most useful immunohistochemical marker for central neurocytoma. NSE is rather non-specific, and frequently positive in oligodendrogliomas and ependymomas $^{5}$. Soylemezoglu et al. ${ }^{10}$ proposed a novel antigen, neuronal nuclear antigen (NeuN), as a reliable neuronal marker in the differential diagnosis of clear cell neoplasms of the CNS.

Negativity for neurofilament protein, observed in our cases, was also found in 10 of the 11 cases of von Deimling et al. ${ }^{2}$ and in 17 cases of Figarella-Branger et al. ${ }^{11}$. In the only positive case in the former series, the tumor showed mature ganglion cells. Advanced ganglionic differentiation is rare in central neurocytomas. In the series of Robbins et al. ${ }^{5}$, only one of seven cases had ganglion cells and expressed NF. These authors found no positivity for chromogranin, present in both our cases.

Several cells in both cases showed strong cytoplasmic reaction for GFAP, in spite of being small and with simple morphology. Similar results were obtained with vimentin and S-100 protein, which usually stain astrocytes. GFAP positive cells have been reported in central neurocytomas and two interpretations have been proposed: they could be trapped pre-existing astrocytes ${ }^{5,12}$, or tumor cells with astrocytic differentiation ${ }^{3,4}$. Their small size and simple nature led us to endorse the latter view. The nuclei were of similar size and appearance to those of neighboring neoplastic cells.

Neurocytoma cells do have potential for glial differentiation, and co-expression of glial and neuronal antigens has been documented by doublelabel immunostaining ${ }^{3}$. von Deimling et al. ${ }^{2}$ found GFAP-positive cells in two of eleven central neurocytomas and noted co-expression of GFAP and synaptophysin in some cells using immunohistochemistry. With immunoblotting co-expression was found in three of four cases.

Ishiuchi and Tamura4 demonstrated simultaneous expression of GFAP and synaptophysin in the same cells in culture. This approach has shown undiffe rentiated cells, cells with neuronal differentia tion positive for neurofilament and containing neurosecretory granules, and cells positive for GFAP. Tumor cells were likened to the subependymal matrix present in the lateral ventricles during fetal and early postnatal life, which gives rise to maturing neurons and glia. Central neurocytoma may thus be derived from remnants of matrix cells retaining potential for divergent differentiation ${ }^{2}$.

With electron microscopy, synapses are rare. We observed several profiles containing secretory vesicles in case 1, but well characterized synapses were found only occasionally. In case 2 , even vesicle containing cell processes were rare. Ishiuchi and Tam u$\mathrm{ra}^{4}$ found only one or two synapses in multiple samples from three patients.

The best treatment for central neurocytoma appears to be complete surgical resection. Patients with incomplete excision may benefit from radiotherapy ${ }^{13,14}$. The tumor is considered of good prognosis, but a mib-1 index higher than $2 \%$ appears to indicate otherwise ${ }^{15,16}$. Two of eleven central neurocytomas ${ }^{2}$ showed focal necrosis, mitoses and vascular proliferation, and other such cases are on re$\operatorname{cord}^{17,18}$. Peritoneal dissemination of a third ventricle and thalamic central neurocytoma in a 3-yearold boy has been reported three and half years after ventriculo-peritonial shunting ${ }^{19}$. Intraventricular hemorrhage initiating in a central neurocytoma has also been observed ${ }^{20}$.

Acknowledgements - Expert technical assistance by Divani de Fátima de Almeida, Priscila Duarte (paraffin histology), Cristiano Aparecido Chagas, Tarsis Eduard o Prates, Júlio César de Moraes (immunohistochemistry), Geralda Domiciana de Pádua and Marilúcia Ruggiero Martins (electron microscopy) is gratefully acknowledged. 


\section{REFERENCES}

1. Hassoun J, Gambarelli D, Grisoli F, et al. Central neurocytoma: an electron-microscopic study of two cases. Acta Neuropathol (Berl) 1982; 56:151-156.

2. von Deimling A, Janzer R, Kleihues P, Wiestler OD. Patterns of differentiation in central neurocytoma: an immunohistochemical study of eleven biopsies. Acta Neuropathol (Berl) 1990;79:473-479.

3. Tsuchida T, Matsumoto M, Shirayama Y, Imahori T, Kasai H, Kawamoto K. Neuronal and glial characteristics of central neurocytoma: electron microscopical analysis of two cases. Acta Neuropathol (Berl) 1996; 91:573-577.

4. Ishiuchi S, Tamura M. Central neurocytoma: an immunohistochemical, ultrastructural and cell culture study. Acta Neuropathol (Berl) 1997; 94:425-435.

5. Robbins P, Segal A, Narula S, et al. Central neurocytoma: a clinicopathological, immunohistochemical and ultrastructural study of 7 cases. Pathol Res Pract 1995;191:100-111.

6. Schmidt MH, Gottfried ON, von Koch CS, Chang SM, McDermott MW Central neurocytoma: a review. J Neurooncol 2004;66:377-384.

7. Zhang B, Luo B, Zhang Z, Sun G, Wen J. Central neurocytoma: a clinicopathological and neuroradiological study. Neuroradiology 2004;46:888-895.

8. Nishio S, Morioka T, Suzuki S, Fukui M. Tumours around the foramen of Monro: clinical and neuroimaging features and their differential diagnosis. J Clin Neurosci 2002;9:137-141.

9. Shin JH, Lee HK, Khang SK, et al. Neuronal tumors of the central nervous system: radiologic findings and pathologic correlation. Radiographics 2002;22:1177-1189.

10. Soylemezoglu F, Onder S, Tezel GG, Berker M. Neuronal nuclear anti- gen (NeuN): a new tool in the diagnosis of central neurocytoma. Pathol Res Pract 2003;199:463-468.

11. Figarella-Branger D, Pellissier JF, Daumas-Duport C, et al. Central neurocytomas: critical evaluation of a small-cell neuronal tumor. Am J Surg Pathol 1992;16:97-109.

12. Kubota T, Hayashi M, Kawano H, et al. Central neurocytoma: immunohistochemical and ultrastructural study. Acta Neuropathol (Berl) 1991;81:418-427.

13. Rades D, Fehlauer F. Treatment options for central neurocytoma. Neurology 2002;59:1268-1270.

14. Kulkarni V, Rajshekhar V, Haran RP, Chandi SM. Long-term outcome in patients with central neurocytoma following stereotactic biopsy and radiation therapy. Br J Neurosurg 2002;16:126-132.

15. Ashkan K, Casey AT, D'Arrigo C, Harkness WF, Thomas DG. Benign central neurocytoma. Cancer 2000;89:1111-1120.

16. Christov C, Adle-Biassette H, Le Guerinel C. Recurrent central neurocytoma with marked increase in MIB-1 labelling index. Br J Neurosurg 1999;13:496-499.

17. Soylemezoglu F, Scheithauer BW, Esteve J, Kleihues P. Atypical central neurocytoma. J Neuropathol Exp Neurol 1997;56:551-556.

18. Kuchiki H, Kayama T, Sakurada K, Saino M, Kawakami K, Sato S. Two cases of atypical central neurocytomas. Brain Tumor Pathol 2002;19:105-110.

19. Coelho M Neto, Ramina R, Meneses MS, A r ruda WO, Milano JB. Peritoneal dissemination from central neurocytoma: case report. Arq Neuropsiquiatr 2003;61:1030-1034.

20. Hanel RA, Montano JC, Gasparetto E, Ditzel LF, Torres LF, Araujo JC. Neurocitoma central com apresentação incomum por hemorragia intraventricular: relato de caso. Arq Neuropsiquiatr 2001;59:628-632. 